\title{
Editorial
}

\section{Thin capitalization and the OECD Model Convention}

\author{
Bruno Gouthière, * Partner International Tax Department, Bureau Francis Lefebvre, Paris
}

Everybody knows that, as a matter of principle, financial expenses are deductible from the company's gross income, like business expenses generally. However, tax laws of various jurisdictions often provide that where the lender is associated with, controlled by or in control of, the borrowing company, unlimited deductibility of interest may be restricted by specific rules. Special considerations come into play in determining deductibility in relation to permissible debt-equity ratios.

For example, French tax legislation provides that deductibility of interest paid to a company's associates for money advanced or loaned to their company, is subject to three conditions.

The first condition, which is also the easiest to understand, is that the company's capital must be entirely paid up.

As for the second condition, a company taxed in France can only be granted an interest deduction on loans from shareholders to the extent that the interest rate does not exceed the average annual interest rate at issue of bonds issued by private companies in France. The tax administration determines this maximum rate, which is periodically published in the Official Gazette (8.95 per cent for 1989).

The third condition concerns managing associates (Section 212 of the French Tax Code). Companies are able to deduct interests paid to associates who legally or 'de facto' manage the company only to the extent that their total loans or advances do not exceed 1.5 times the company's share capital. However, this limitation does not apply to interests paid by French companies to their parent companies, this expression being defined by Section 145 of the Code which implies that they are subject to French corporation tax.

Interests paid in excess of those limits are not deductible for corporation tax purposes and are treated as distribution of dividends.

Many tax jurisdictions apply similar concepts, although not always so precisely defined by tax laws, whereby, in certain circumstances, part of interests paid to an associate are disregarded and treated as a distribution of dividends. When it comes to a foreign associate resident in a Treaty country, this raises the question of the compatibility of such treatment with the wording of the Treaty. If we consider the OECD 1977 model convention, various articles have then to be considered.

The first Article would certainly be Article 9 of the Model Treaty on associated enterprises, which gives to the State of residence of the company paying the interests the right to include in the profits of such company, and to tax accordingly, any income transferred to another company (the lender) by reason of commercial or financial conditions which differ from those which would be made between independent enterprises. Such provision may be interpreted as allowing the State of residence of the company paying the interest to apply its own rules with respect to thin capitalization, provided that it can be proved that the transaction is not arm's length.

Once the adjustment is made, two other Articles have to be considered, i.e. Article 10 on dividends and Article 11 on interest; in the OECD view, excess interests can be treated as dividends, giving therefore to the source country the right to levy a withholding tax. Such was not the attitude of the French Supreme Court (Conseil d'État), for example, which decided that the wording of the OECD definition was not precise enough to permit such assimilation, at least where the recipient is not a shareholder of the paying company. This is the reason why the most recent Treaties signed by France are based on a different definition, whereby the term 'dividends' means also income treated as a distribution by the taxation laws of the

* Bruno Gouthière, Bureau Francis Lefebvre, Paris, formerly Deputy Director, International Tax Department, French Ministry of Finance. 
State of which the company making the distribution is a resident. French Courts have ruled that this wording gives France the right to levy a withholding tax.

Turning to the potential consequences in the State of the company which receives the excess interests, Article 23 of the Model, which provides for the elimination of double taxation, must be considered, in relation with Article $9 \S 2$ on the tricky issue of correlative adjustment and Article 25 on mutual agreement procedure. As everybody knows, such provisions are useful but the adjustment has no automatic character and the competent authorities are only required to seek a solution but are not under an obligation to find one. This is the reason why the efforts made by the EC Commission towards the introduction of an arbitration procedure within the EC should be encouraged. This is not to say that bilateral arbitration procedures should not at the same time be encouraged, as shown, for example, in the recent Protocol (not yet in force) between France and Germany.

Finally, and perhaps most importantly in some cases, one has to consider Article 24 of the Model, on nondiscrimination. It is not uncommon that domestic tax laws seek to treat differently excess interests paid to foreign entities and to domestic entities. This is notably the case in France, where the special limitation provided by Section 212 of the Code does not apply to French parent companies or, under the same conditions to French permanent establishments of foreign entities, whereas it applies to interests paid to nonresident parent companies if the shares are not held by a French PE of such company. Actually, this seems to be a good example of discrimination prohibited by the Model Treaty, for two reasons. Firstly, the interests paid by a resident of one Contracting State should be deductible under the same conditions whether the recipient is an enterprise resident of the other Contracting State or of the first mentioned State (Article $24 \$ 5$ ). Secondly, and more importantly, (because of possible critical remarks with respect to the first reason) Article $24 \$ 6$ provides that enterprises of a Contracting State, the capital of which is wholly or partly owned or controlled directly or indirectly by one or more residents of the other Contracting State shall not be subject in the first mentioned State to any taxation which is other or more burdensome than the taxation and connected requirements to which other similar enterprises of the first mentioned State are or may be subjected. This provision aims at ensuring equal treatment for taxpayers residing in the same State irrespective of the fact that their capital is or not controlled by residents of such State. This is why, in particular, it should prevent France from refusing deductibility of interests when paid to a foreign parent whereas such deductibility is allowed when the parent is a French resident. The fact that the French Conseil d'Etat recently decided that the nondiscrimination clause included in the France-Sweden Treaty had no bearing on this issue is, to our mind, irrelevant since this Treaty is an old one and is not based on the OECD wording. ${ }^{1}$

It is therefore everyday clearer that the impact of nondiscrimination provisions will be more and more important in the future, as courts, in various jurisdictions, no longer hesitate to give their own interpretation of these clauses. This is even more certain within the EC, and, as the European Court has an extensive interpretation of the nondiscrimination principle, one can even wonder if the difference made by national tax laws between resident and nonresident will still be relevant in the future. 